\title{
Distribution and Characterization of Aeroallergens in the Etiology of Allergic Rhinitis Patients in İstanbul Kartal Region
}

\author{
Istanbul Kartal Bölgesi Alerjik Rinit Hastalarının Etiyolojisindeki Aeroalerjenlerin Dağılımı ve \\ Karakterizasyonu
}

\author{
(D) Kadriye TERZioĞLU1, (D) Meltem AĞCA ÇOBAN² \\ ${ }^{1}$ Kartal Dr. Lütfü Kırdar City Hospital, Clinic of Internal Disease, İstanbul, Turkey \\ 2 Istanbul Süreyyapaşa Chest Diseases and Thoracic Surgery Training and Research Hospital, Clinic of Intensive Care, Istanbul, Turkey
}

\begin{abstract}
Aim: Allergic rhinitis (AR) is a common disease and the first step in its treatment is to determine the allergen responsible for its etiology and to take preventive measures. The aim of this study was to determine the distribution of aeroallergens in AR patients in İstanbul Kartal region and to investigate other factors affecting the severity of AR.

Materials and Methods: The study was performed in a tertiary hospital on the Anatolian side of İstanbul among patients who were admitted to the allergy and clinical immunology outpatient clinic and diagnosed with AR. Data of patients were obtained from medical records retrospectively. Age, gender, concomitant atopic disease, family transition history, serum total IgE and serum eosinophil (Eo) levels were evaluated. Skin prick tests were performed with 25 allergens.

Results: One hundred and sixty patients were included in our study. Ninety-six (65.8\%) of the patients were female and the median age of the study population was 31 (18-75) years. Distribution of aeroallergens according to skin test results was as follows; D. pteronyssinus (78.1\%), D. farinae (75.2\%), Tyrophagus putrescentlae (59.6\%), Acurus siro (57.5\%), Lepidoglyphus destructor (40.4\%), cereals mix (37.7\%), and cat hair (33.6\%). It was found that there was a significant increase in total $\lg E$ levels $(p<0.001)$ consistent with the increase in serum Eo level.

Conclusion: In our study, mite sensitivity has been found to be the most common allergen sensitivity in accordance with the geographic and climatic characteristics of the İstanbul region. Secondly, cat hair sensitivity and pollen (grasses mix) sensitivity were similarly high due to the increase in the number of domestic animals in the modern age. We think that our study contributes to the literature by examining the distribution of these allergens that cause AR and patients are guided to take preventive measures in this regard.
\end{abstract}

Keywords: Allergic rhinitis, aeroallergen, sensitization

ÖZ

Amaç: Alerjik rinit (AR) yaygın görülen bir hastalıktır ve tedavisinde ilk basamak, etiyolojisindeki sorumlu alerjeni saptayıp koruyucu önlemleri almaktır. Çalışmamızın amacı, İstanbul Kartal yerleşkesinde yaşayan AR hastalarının etiyolojisinde rol alan aeroalerjenlerin dağılımını tespit etmek ve AR şiddetini etkileyen faktörleri araştırmaktır.

Gereç ve Yöntem: Çalışma, İstanbul Anadolu yakasında bulunan üçüncü basamak bir hastanede gerçekleştirildi. Alerji ve klinik immünoloji polikliniğine rinit şikayeti ile başvurup AR tanısı konulan hastalar çalışmaya dahil edildi ve dosyaları geriye dönük olarak incelendi. Hastaların yaş, cinsiyet, eşlik eden diğer atopik hastalıkları, aile geçiş öyküsü, serum total IgE ve serum eozinofil (Eo) seviyeleri değerlendirildi. Deri prick testleri 25 adet alerjen ile yapıldı.

Bulgular: Çalışmamıza 146 hasta dahil edildi. Hastaların 96'sı $(\% 65,8)$ kadındı. Medyan yaş $31(18-75)$ yıl olarak saptandı. Deri prick test sonuçlarına göre aeroalerjenlerin dağılımı sırasıyla; D. pteronyssinus $(\% 78,1)$, D. farinae $(\% 75,2)$, Tyrophagus putrescentlae $(\% 59,6)$, Acurus siro $(\% 57,5)$,

Address for Correspondence: Kadriye TERZioĞLU MD, Kartal Dr. Lütfü Kırdar City Hospital, Clinic of Internal Disease, İstanbul, Turkey E-mail: dr.kadriyete@gmail.com ORCID ID: orcid.org/0000-0002-0674-417X

Received: 15.11.2020 Accepted: 23.02.2021

๑Copyright 2021 by the Tekirdağ Namık Kemal University Faculty of Medicine / Namık Kemal Medical Journal published by Galenos Publishing House. 
Lepidoglyphus destructor $(\% 40,4)$, cereals mix $(\% 37,7)$, kedi tüyü $(\% 33,6)$ şeklindeydi. Hastaların serum Eo seviyesindeki artışa paralel olarak total $\lg$ E düzeylerinde de anlamlı artış olduğu $(p<0,001)$ görüldü.

Sonuç: Çalışmamızda, İstanbul bölgesinin coğrafik yapısı ve iklimi ile uyumlu olarak en fazla akar duyarlılığı saptandı. İkinci olarak modern çağda ev içi hayvan besleme sayısında artmaya bağlı olarak kedi tüyü duyarlılığı ve polen (grasses mix) duyarlılığı benzer şekilde yüksek oranlarda saptandı. Çalışmamızın AR'ye sebep olan aeroalerjenlerin dağılımını inceleyerek literatüre katkı sağladığını ve hastaların bu yönde koruyucu önlemlerini almaları için yol gösterici olacağını düşünmekteyiz.

Anahtar Kelimeler: Alerjik rinit, aeroalerjen, duyarlılık

\section{INTRODUCTION}

Allergic rhinitis (AR) is a type $1 \mathrm{lgE}$-mediated disease of the nasal mucosa and is characterized by recurrent sneezing, runny nose, and nasal congestion'. Although its prevalence varies according to countries and age, it affects $10-20 \%$ of the population². Detection of aeroallergens that cause allergic sensitization in $A R$ and minimizing exposure are important components of the treatment plan.

Distribution of aeroallergens varies depending on geographical structure, seasons, socioeconomic and cultural structures ${ }^{3}$. In recent years, with the increase in AR prevalence, differences in the distribution of aeroallergens have begun to be detected. Various factors have been identified that lead to this situation, some of which are the hygiene hypothesis, the increase in the time spent indoors in parallel with the technological development, the increase in the release of various allergens such as ragweed pollen and aspergillus fumigatus into the atmosphere due to global climate change and gases released in the airr-6.

Our aim in the study is to investigate the distribution of aeroallergens that play a role in the etiology of AR patients living in İstanbul Kartal region and the factors affecting $A R$ severity.

\section{MATERIALS AND METHODS}

The study was carried out in a tertiary healthcare institution located on the Anatolian side of İstanbul. Patients who applied to the allergy and clinical immunology outpatient clinic with rhinitis symptoms and were diagnosed with AR were included in the study. The study were approved by the Kartal Dr. Lütfi Kırdar City Hospital Clinical Research Ethics Committee (protocol number: 2020/514/180/17, date: 26.06.2020).

\section{Patient Selection}

The files of patients admitted with AR between January and March 2020 were retrospectively reviewed. AR diagnosis of all patients was confirmed according to Allergic Rhinitis and its Impacts on Asthma (ARIA) guidelines, and patients with positive skin prick test were included in the study. Patients' age, gender, severity of rhinitis, year of $A R$, blood eosinophil (Eo) and total $\lg$ E values, accompanying atopic diseases (asthma, urticaria, eczema), comorbidity, and family history were investigated. Values of $0.2 \mu \mathrm{gr}$ (normal range 0-0.2 $\mu \mathrm{gr}$ ) for Eo elevation and $100 \mathrm{UI} / \mathrm{mL}$ (normal range 0-100 $\mathrm{UI} \mathrm{mL}$ ) for $\lg E$ elevation were accepted. The AR classification and severity of the patients were made according to ARIA (mild intermittent, moderate-severe intermittent, mild persistent, moderate-severe persistent). Intermittent AR; symptoms less than four days a week and lasting less than four consecutive weeks. Persistent AR; symptoms more than four days a week lasting for four consecutive weeks. Symptoms were classified as mild if they did not affect sleep, daily activities, work-school activities, and as moderate-severe if they affected ${ }^{7}$ them.

\section{Skin Prick Test}

Skin prick test was conducted with 25 allergens (grasses mix, cereals mix, tree mix, Dermatophagoides (D.) pteronyssinus, Dermatophagoides farinae, Acarussiro, cockroach, cat hair, dog hair, Aspergillus fumigatus, Alternaria, Clodosporium, Lepidoglypus destructr, Tyrophagus putrescentlae, wormwood, stickygrass, plantain, grapegrass, hazel, alder, ash, olive, birch, oak, and poplar) and standard commercial allergens were used (Alk-Abello, Lincoln Diagnostics, Dallas, TX, USA). The skin prick test was performed on the anterior surface of both arms in accordance with international guidelines. Histamine $(10 \mathrm{mg} /$ $\mathrm{mL}$ ) was used as the positive control and $0.09 \%$ sterile saline was used as the negative control. The test was considered positive if the edema diameter at the test site after 20 minutes was found to be more than $3 \mathrm{~mm}$ compared to the negative control ${ }^{8}$.

\section{Statistical Analysis}

Data statistics were performed using Statistical Package for the Social Sciences (SPSS) 22.0 (SPSS for Windows, version 19.0). The normality of the data distribution was checked with the Kolmogorov-Smirnov test. Quantitative variables were expressed as mean \pm standard deviation or median $\left(25^{\text {th }}-75^{\text {th }}\right.$ percentile), categorical variables were expressed as percentages. Student's t-test or Mann-Whitney U test was used to compare the differences of continuous variables. The $x^{2}$ test was used to compare categorical variables. Relationships between continuous variables were calculated with the Spearman correlation coefficient. $P$ value of $<0.05$ was considered statistically significant. 


\section{RESULTS}

Of the 146 AR diagnosed patients included in the study, 96 $(65.8 \%)$ were female. The median age in the study group was 31 (18-75) years. When the severity of rhinitis was classified, mild persistent $35.6 \%$, moderate-severe persistent $22.6 \%$, mild intermittent 21.2\%, moderate-severe intermittent 20.5\% were found in order of frequency. In 45.9\% of the patients, the rhinitis duration was longer than 5 years. As comorbid diseases, asthma was the first with $26.7 \%$, eczema was $18.5 \%$ and urticaria was 6.8\%. Elevated blood Eo was detected in 60 patients (41.1\%), and total IgE elevation was found in 78 patients (53.4\%) (Table 1). In Spearman correlation analysis, a positive and significant correlation was found between blood Eo value and total $\lg E(r=0.335 ; p<0.001)$ (Figure 1). When the family history of the patients was questioned; most of

\section{Table 1. General data of patients with allergic rhinitis}

\begin{tabular}{|c|c|c|}
\hline & $\mathbf{n}$ & $\%$ \\
\hline \multicolumn{3}{|l|}{ Gender } \\
\hline Female & 96 & 65.8 \\
\hline Male & 50 & 34.2 \\
\hline \multicolumn{3}{|c|}{ Allergic rhinitis severity classification } \\
\hline Mild intermittent & 31 & 21.2 \\
\hline Moderate to severe intermittent & 30 & 20.5 \\
\hline Mild persistent & 52 & 35.6 \\
\hline Moderate to severe persistent & 33 & 22.6 \\
\hline \multicolumn{3}{|l|}{ Duration of allergic rhinitis } \\
\hline $0-1$ year & 25 & 17.1 \\
\hline $1-5$ years & 54 & 37 \\
\hline Over 5 years & 67 & 45.9 \\
\hline \multicolumn{3}{|l|}{ Serum eosinophilia } \\
\hline$<0.2 \mu \mathrm{gr}$ & 86 & 58.9 \\
\hline$>0.2 \mu \mathrm{gr}$ & 60 & 41.1 \\
\hline \multicolumn{3}{|l|}{ Total $\lg \mathrm{E}$} \\
\hline 0-100 UI/mL & 68 & 46.6 \\
\hline 100-500 UI/mL & 55 & 37.7 \\
\hline$>500 \mathrm{UI} / \mathrm{mL}$ & 23 & 15.8 \\
\hline \multicolumn{3}{|l|}{ Asthma } \\
\hline Yes & 39 & 26.7 \\
\hline None & 107 & 73.3 \\
\hline \multicolumn{3}{|l|}{ Urticaria } \\
\hline Yes & 10 & 6.8 \\
\hline None & 136 & 93.2 \\
\hline \multicolumn{3}{|l|}{ Eczema } \\
\hline Yes & 27 & 18.5 \\
\hline None & 119 & 81.5 \\
\hline \multicolumn{3}{|l|}{ Comorbid } \\
\hline Yes & 17 & 11.6 \\
\hline None & 129 & 88.4 \\
\hline
\end{tabular}

the patients $(79.5 \%, n=116)$ had a family history. While the majority of patients with a family history were female (69.8\%, $\mathrm{n}=81$ ), the difference was significant compared to male gender $(p=0.041)$.

\section{Distribution of Sensitization to Aeroallergens}

The allergens that were found to be positive in the skin prick test results of the patients, in order of frequency were: D. pteronyssinus (78.1\%), D. farinae (75.2\%), Tyrophagus putrescentlae (59.6\%), Acurus siro (57.5\%), Lepidoglyypus destructor (40.4\%), cereals mix (37.7\%), cat hair (33.6\%), grasses mix (31.5\%), dog hair (29.5\%), cocroaches $(21.2 \%)$, plantain (14.4\%) and wormwood (13.7\%) (Figure 2).

In total, any house dust mite and/or warehouse mite positivity was $89 \%(n=130)$, sensitivity to any pollen group (grass, grain, tree, weeds) was $52.7 \%(n=77)$ and sensitivity to any mold fungus was $13.7 \%(n=20)$ and no significant difference was found between the female and male genders in terms of sensitivity distributions ( $p=0.569, p=0.789, p=0.939)$. Among the aeroallergens, while cat hair sensitivity was found to be significantly higher in those who were sensitive to mold fungus and pollen ( $p=0.007, p<0.000$, respectively), a similar relationship was not found in mite sensitivity $(p=0.742)$.

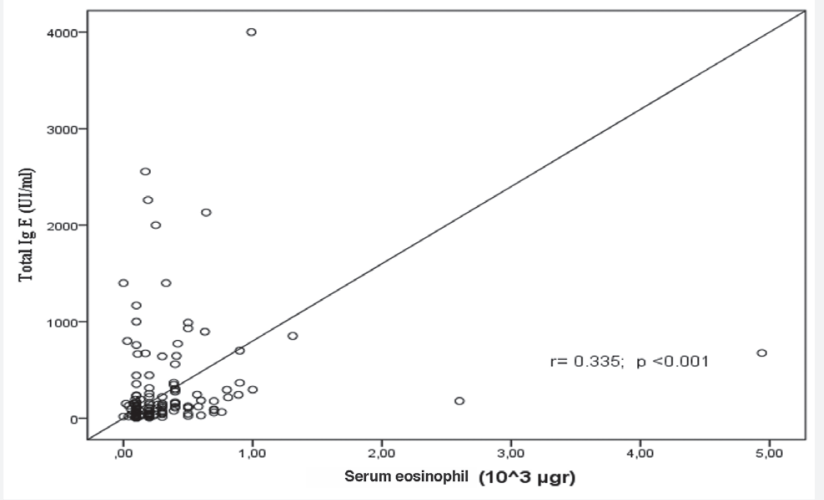

Figure 1. Correlation between serum eosinophil and total $\lg \mathrm{E}$

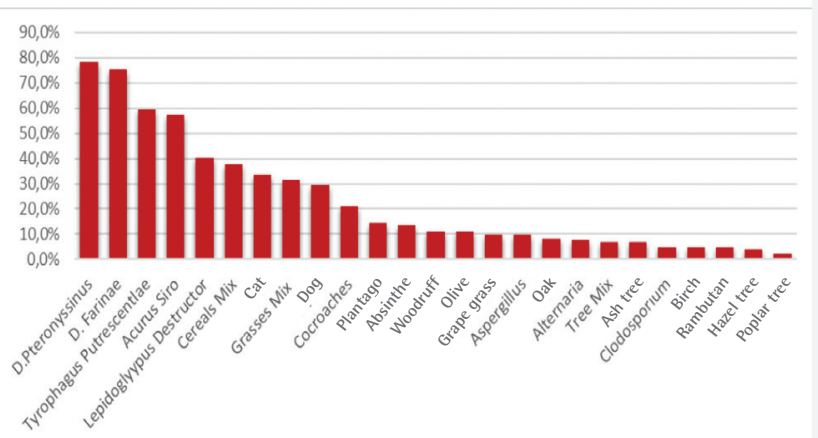

Figure 2. Distribution of sensitization to aeroallergens 
When the characteristics and laboratory findings of the patients were evaluated according to the severity of $A R$, no significant difference was found (Table 2). AR severity and aeroallergen distributions are given in Figure 3 and Figure 4 .

\section{DISCUSSION}

Allergens play an important role in the etiology of AR. The distribution of allergens and their effects on individuals may vary depending on geographical regions, socioeconomic level, living conditions and genetic structure. In our study, when the aeroallergen distribution of AR patients in the İstanbul Kartal region was examined, it was determined that $D$. pteronyssinus $78.1 \%$, D. farinae $75.2 \%$, Tyrophagus putrescentlae $59.6 \%$, Acurus siro $57.5 \%$ and Lepidoglypus destructor $40.4 \%$ were in the top five with mite sensitivity and then pollen and cat hair sensitivity were determined to be effective. The ideal humidity for the reproduction and accumulation of house dust mites is $65-80 \%$ and they die at humidity levels below $50 \%{ }^{9}$. In studies from various geographical regions around the world, it was shown that the level of dust mite was clinically insignificant at high altitudes such as New Mexico Alamos region (2,195 m), Italy Misurina region $(1,756 \mathrm{~m})$, and in cold climate regions such as Sweden Norbotten, where the average temperature is -10 to $15^{\circ} \mathrm{C}$ and humidity is $0 \%{ }^{10-12}$. However, İstanbul has an

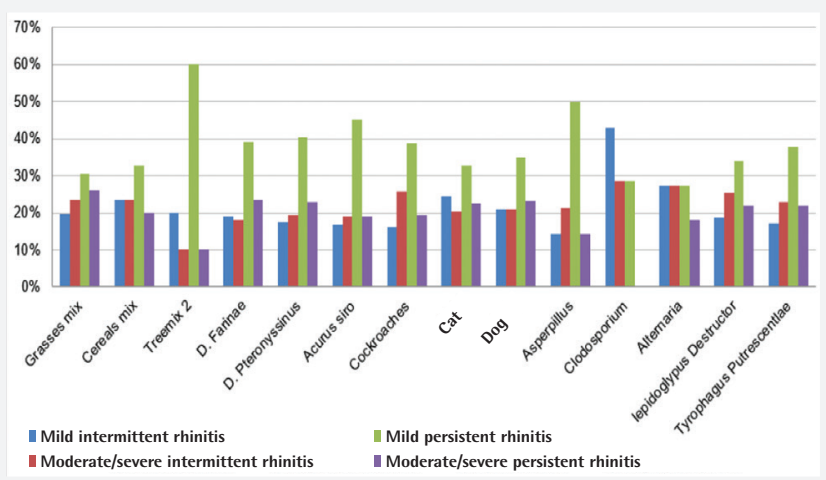

Figure 3. Distribution of aeroallergens by severity classification of allergic rhinitis

\section{Table 2. Evaluation of factors affecting the severity of allergic rhinitis}

\begin{tabular}{|l|l|l|l|l|}
$\begin{array}{l}\text { Mild intermittent } \\
\mathbf{n}(\%)\end{array}$ & $\begin{array}{l}\text { Moderate-severe } \\
\text { intermittent } \mathbf{n}(\%)\end{array}$ & $\begin{array}{l}\text { Mild persistent } \\
\mathbf{n}(\%)\end{array}$ & $\begin{array}{l}\text { Moderate-severe } \\
\text { persistent } \\
\mathbf{n}(\%)\end{array}$ & $\mathbf{p}^{*}$
\end{tabular}

\section{Age (years)}

\begin{tabular}{|c|c|c|c|c|c|}
\hline $18-29$ & $10(6.8)$ & $15(10.3)$ & $22(15.1)$ & $18(12.3)$ & \multirow{3}{*}{0.532} \\
\hline $30-49$ & $15(10.3)$ & $13(8.9)$ & $24(16.4)$ & $12(8.2)$ & \\
\hline$>50$ & $6(4.1)$ & $2(1.4)$ & $6(4.1)$ & $3(2.1)$ & \\
\hline \multicolumn{6}{|l|}{ Gender } \\
\hline Female & $25(17.1)$ & $20(13.7)$ & $35(24)$ & $16(11)$ & \multirow{2}{*}{0.058} \\
\hline Male & $6(4.1)$ & $10(6.8)$ & $17(11.6)$ & $17(11.6)$ & \\
\hline \multicolumn{6}{|c|}{ Rhinitis duration (years) } \\
\hline $0-1$ & $6(4.1)$ & $8(5.5)$ & $6(4.1)$ & $5(3.4)$ & \multirow{3}{*}{0.502} \\
\hline $1-5$ & $14(9.6)$ & $8(5.5)$ & $19(13)$ & $13(8.9)$ & \\
\hline$>5$ & $11(7.5)$ & $14(9.6)$ & $27(18.5)$ & $15(10.3)$ & \\
\hline \multicolumn{6}{|c|}{ Concomitant atopy } \\
\hline Asthma+ & $8(5.5)$ & $7(4.8)$ & $17(11.6)$ & $7(4.8)$ & \multirow{2}{*}{0.649} \\
\hline Asthma- & $23(15.8)$ & $23(15.8)$ & $35(24)$ & $26(17.8)$ & \\
\hline Urticaria+ & $2(1,4)$ & $2(1.4)$ & $5(3.4)$ & $1(0.7)$ & \multirow{2}{*}{0.709} \\
\hline Urticaria- & $29(19.9)$ & $28(19.2)$ & $47(32.2)$ & $32(21.9)$ & \\
\hline Eczema+ & $4(2.7)$ & $6(4.1)$ & $13(8.9)$ & $4(2.7)$ & \multirow{2}{*}{0.386} \\
\hline Eczema- & 27 (18.5) & $24(16.4)$ & $39(26.7)$ & $29(19.9)$ & \\
\hline \multicolumn{6}{|c|}{ Serum eosinophilia $\left(10^{3} \mu \mathrm{gr}\right)$} \\
\hline$\leq 0.2$ & 18 (12.3) & $19(13.0)$ & $33(22.6)$ & $16(11)$ & \multirow{2}{*}{0.536} \\
\hline$>0.2$ & $13(8.9)$ & $11(7.5)$ & $19(13)$ & $17(11.6)$ & \\
\hline \multicolumn{6}{|c|}{ Serum total $\lg E(\mathrm{Ul} / \mathrm{mL})$} \\
\hline $0-100 \mathrm{U}$ & $17(11.6)$ & $14(9.6)$ & $19(13)$ & $18(12.3)$ & \multirow{3}{*}{0.675} \\
\hline $100-500$ & $10(6.8)$ & $11(7.5)$ & $24(16.4)$ & $10(6.8)$ & \\
\hline$>500$ & $4(2.7)$ & $5(3.4)$ & $9(6.2)$ & $5(3.4)$ & \\
\hline
\end{tabular}




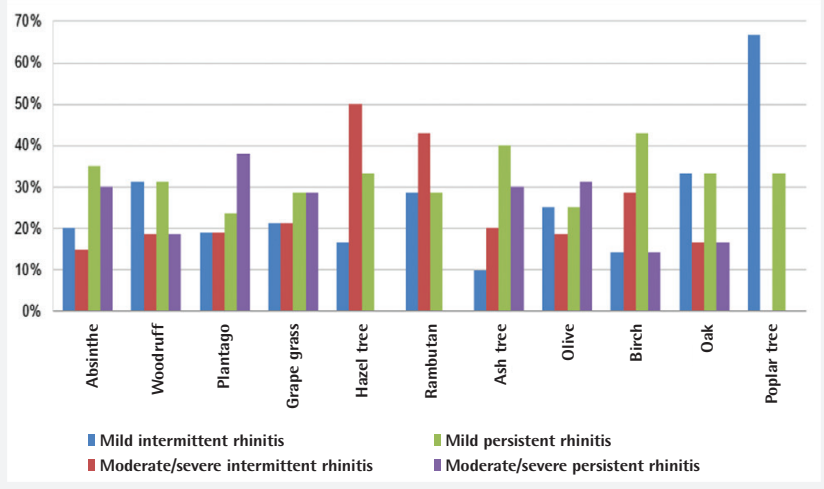

Figure 4. Distribution of aeroallergens by severity classification of allergic rhinitis

altitude at sea level, the lowest temperature is -11 , the highest temperature is +40 degrees, the average relative humidity is $75 \%$, and this rate goes up to $80-85 \%$ in certain months.

As a result, İstanbul has a climate with high humidity most of the year due to its geographical structure. For this reason, a high mite sensitivity rate is an expected result. In studies from different regions of Turkey, sensitivity rates for house mites D. pteronyssinus and D. farinae were $72.5 \%$ and $63.7 \%$ in Düzce, 62.2\% and 51.3\% in Eskişehir, 50\% and 44\% in Bursa, and 84\% and $78.2 \%$ in the Eastern Black Sea region, which is similar to the data obtained in our study ${ }^{13-16}$. The high sensitivity to house dust mites in our study is thought to be due to the high humidity and mild climate of the İstanbul Kartal region, which is located at sea level. In a recent study by Ediger et al. ${ }^{15}$, the most frequently observed aeroallergens in Bursa region after D. pteronyssinus and D. farine were grasses mix (38.6\%), olive (33.2\%), cereals pollen (32.3\%), Acarus siro (26.3\%) and cat hair $(12 \%)^{14}$.

In our study, the sensitivity rate of Acarus siro was found to be approximately 2 times higher with $57.5 \%$, and the sensitivity rate of cereals $\operatorname{mix}(37.7 \%)$ and grasses $\operatorname{mix}(31.5 \%)$ was similar. It is an expected result that olive pollen causes high sensitivity similar to grasses mix due to olive cultivation in Bursa region. In our study, sensitivity to olive tree pollen was found to be lower (11\%). This result shows that geographical vegetation closely affects the allergen etiology in AR patients. According to the results, it is important for allergy specialists to create an allergen panel according to the characteristics of the geography they are in.

Another remarkable point obtained in our study is that the rate of cat sensitivity (33.6\%) in AR patients is higher than the grasses $\operatorname{mix}(31.5 \%)$, which is one of the main allergens, and it ranks third after the mite and cereals (grain) mix. The cat sensitivity rate in Europe is estimated at around $27 \%{ }^{17}$. It is thought that this high sensitivity causes an increase in the amount of cat allergens in places where there are no cats (school, work, nursery) as a result of the increase in domestic cat feeding rates in industrialized countries, and this contributes to sensitization ${ }^{18,19}$. This result was supported by the study of Gulbahar et al. ${ }^{20}$ in 387 patients. Although the cat sensitivity rate was found to be $44.7 \%$ in this study, it was reported that only $1.6 \%$ of the patients kept cats at home.

Another interesting point obtained in our study was that cat hair sensitivity was found to be significantly higher in individuals with mold and pollen sensitivity. Albumindependent cross-reactivity is known to be among cat hair and dog hair allergens, but no known cross-reactivity has been detected between molds and pollen groups. Further studies with larger series are needed for the significance of this data.

It is known that genetic transmission is an important factor in the formation of AR. If there is no history of allergy in the parents, the probability of $A R$ is $0-10 \%$, if one of the parents has a history of allergy, this rate is $30-40 \%$, if both parents have a history of allergy, this rate can reach $60-70 \%{ }^{21}$. In our study, the presence of allergy history in the mother and/or maternal relatives was 58.2\%, and the family history positivity was found to be significantly higher in females than males. This result indicates that the female gender carries the diseased gene at a higher rate.

Recently, AR and asthma have been defined as the single airway diseases, and there are many studies showing elevated serum Eo and total IgE in parallel with airway inflammation in these diseases ${ }^{22,23}$. Similarly, in our study, the total IgE level of patients with $A R$ was found to be significantly higher than the normal population. In the correlation analysis, it was observed that there was a positive correlation between serum total IgE and serum Eo count. These results show the importance of evaluating the total IgE and Eo levels together in patients with AR. However, no significant correlation was found between total IgE elevation and AR severity in our cohort. Similarly, no significant relationship was found between the severity of AR and age, gender, type of aeroallergen, and other concomitant atopic diseases.

\section{Study Limitations}

Compared to the population of İstanbul, the small number of patients in our study and the inability to measure serum specific $\lg E$ in correlation with the skin prick test are the limitations of our study.

\section{CONCLUSION}

$A R$ is a disease whose prevalence increases every year and multifactorial factors play a role in its etiology. Along with genetic predisposition, allergens play an important role in the etiology. In this study, mites, pollen and cat hair were in the top three ranks in the distribution of aeroallergens. Considering the differences in the distribution of allergens according to climatic conditions, geographical structure and socioeconomic 
levels, knowing the distribution of allergens in the population admitted to the hospital with AR will guide the patients to take preventive measures in this direction.

\section{Ethics}

Ethics Committee Approval: The study were approved by the Kartal Dr. Lütfi Kırdar City Hospital Clinical Research Ethics Committee (protocol number: 2020/514/180/17, date: 26.06.2020).

Informed Consent: Retrospective study.

Peer-review: Externally peer-reviewed.

\section{Authorship Contributions}

Concept: K.T., Design: K.T., M.A.Ç., Data Collection or Processing: K.T., M.A.Ç., Analysis or Interpretation: M.A.Ç., Literature Search: K.T., Writing: K.T.

Conflict of Interest: No conflict of interest was declared by the authors.

Financial Disclosure: The authors declared that this study received no financial support.

\section{References}

1. Dykewicz MS, Hamilos DL. Rhinitis and sinusitis. J Allergy Clin Immunol. 2010;125(2 Suppl 2):S103-15.

2. Stewart $M$, Ferguson $B$, Fromer L. Epidemiology and burden of nasal congestion. Int J Gen Med. 2010;3:37-45.

3. Seidman MD, Gurgel RK, Lin SY, Schwartz SR, Baroody FM, Bonner JR, et al. Clinical practice guideline: allergic rhinitis executive summary. Otolaryngol Head Neck Surg. 2015;152:197-206.

4. Platts-Mills TAE, Schuyler AJ, Erwin EA, Commins SP, Woodfolk JA. IgE in the diagnosis and treatment of allergic disease. J Allergy Clin Immunol. 2016;137:1662-70.

5. D'Amato G, Vitale C, Lanza M, Molino A, D'Amato M. Climate change, air pollution, and allergic respiratory diseases: an update. Curr Opin Allergy Clin Immunol. 2016;16:434-40.

6. Cecchi L, D'Amato G, Annesi-Maesano I. External exposome and allergic respiratory and skin diseases. J Allergy Clin Immunol. 2018;141:846-57.

7. Brozek JL, Bousquet J, Agache I, Agarwal A, Bachert C, Bosnic-Anticevich S, et al. Allergic Rhinitis and its Impact on Asthma (ARIA) guidelines-2016 revision. J Allergy Clin Immunol. 2017;140:950-8.

8. Nelson HS. Variables in allergy skin testing. In: Dolen W, ed. Skin Testing. Philadelphia, PA: WB Saunders, 2001;21:281-90.
9. Calderón MA, Linneberg A, Kleine-Tebbe J, De Blay F, Hernandez Fernandez de Rojas D, Virchow JC, et al. Respiratory allergy caused by house dust mites: What do we really know? J Allergy Clin Immunol. 2015;136:38-48.

10. Ingram JM, Sporik R, Rose G, Honsinger R, Chapman MD, Platts-Mills TA. Quantitative assessment of exposure to $\operatorname{dog}($ Can $f$ 1) and cat (Fel d 1) allergens: relation to sensitization and asthma among children living in Los Alamos, New Mexico. J Allergy Clin Immunol. 1995;96:449-56.

11. Boner AL, Niero E, Antolini I, Valletta EA, Gaburro D. Pulmonary function and bronchial hyperreactivity in asthmatic children with house dust mite allergy during prolonged stay in the Italian Alps (Misurina, $1756 \mathrm{~m}$ ). Ann Allergy. 1985;54:42-5.

12. Arlian LG, Neal JS, Morgan MS, Vyszenski-Moher DL, Rapp CM, Alexander AK. Reducing relative humidity is a practical way to control dust mites and their allergens in homes in temperate climates. J Allergy Clin Immunol. 2001;107:99-104.

13. Öztürk Ö, Tokmak A, Güçlü E, Yıldızbaş Ş, Gültekin E. Düzce'de allerjik rinitli hastalarda prick testi sonuçları. Düzce Tıp Fakültesi Dergisi. 2005;7:11-4.

14. Harmanci E, Us T, Ozdemir N, Akgun Y, Aydinli A, Mutlu S. The relationship between skin prick tests and serum specific $\operatorname{lgE}$ which is determined by chemiluminescence method in the diagnosis of respiratory system allergies. Solunum. 2000;2:31-5.

15. Ediger $D$, Günaydin $F E$, Erbay $M$, Şeker Ü. Trends of sensitization to aeroallergens in patients with allergic rhinitis and asthma in the city of Bursa, South Marmara Sea Region of Turkey. Turk J Med Sci. 2020;50:3306.

16. Coskun ZO, Erdivanlı OC, Kazıkdas KÇ, Terzi S, Sahin U, Ozgur A, et al. High sensitization to house-dust mites in patients with allergic rhinitis in the eastern Black Sea region of Turkey: A retrospective study. Am J Rhinol Allergy. 2016;30:351-5.

17. Heinzerling LM, Burbach GJ, Edenharter G, Bachert C, Bindslev-Jensen C, Bonini S, et al. GA(2)LEN skin test study I: GA(2)LEN harmonization of skin prick testing: novel sensitization patterns for inhalant allergens in Europe. Allergy. 2009;64:1498-506.

18. Salo PM, Arbes SJ Jr, Jaramillo R, Calatroni A, Weir CH, Sever ML, et al. Prevalence of allergic sensitization in the United States: results from the National Health and Nutrition Examination Survey (NHANES) 2005-2006. J Allergy Clin Immunol. 2014;134:350-9.

19. Simpson A, Custovic A. Pets and the development of allergic sensitization. Curr Allergy Asthma Rep. 2005;5:212-20.

20. Gulbahar O, Sin A, Mete N, Kokuludag A, Kirmaz C, Sebik F. Sensitization to cat allergens in non-cat owner patients with respiratory allergy. Ann Allergy Asthma Immunol. 2003;90:635-9.

21. Kjellman NI. Atopic disease in seven-year-old children. Incidence in relation to family history. Acta Paediatr Scand. 1977;66:465-71.

22. Khadadah $\mathrm{M}$, Onadeko BO, Ezeamuzie $\mathrm{Cl}$, Mustafa HT, Marouf $\mathrm{R}$, Sugathan TN. The association of skin test reactivity, total serum IgE levels, and peripheral blood eosinophilia with asthma in Kuwait. J Asthma. 2000;37:481-8.

23. Howell WM. HLA immunogenetics and specific IgE responses to allergens. Clin Exp Allergy. 1994;24:401-4. 